\title{
Analisa SWOT Strategi Digitalisasi pada Era New Normal untuk Pertumbuhan Ekonomi di Sumatera, Indonesia
}

\author{
RANILA SUCIATI \\ KERY UTAMI \\ BELARDO PRASETYA MEGA JAYA \\ Universitas Pembangunan Nasional Veteran Jakarta, Jakarta, Indonesia \\ JI. RS. Fatmawati, Pondok Labu, Jakarta Selatan, DKI Jakarta, 12450 \\ Email: ranila@upnvj.ac.id
}

Diterima 17 Januari 2021; disetujui 31 Januari 2021;

\begin{abstract}
The spread of COVID-19 has almost never been predicted by any part of the world. This affects most business fields in terms of global supply, world demand, and the confidence of economic actors. The spread of COVID-19 has caused several business activities which become the driving force of the economy stopped due to government policies. The stay at home policy disrupts the performance of the business field, most of which conduct physical buying and selling transactions. And it has directly impact to a negative economic growth both globally and in every region of Indonesia, including Sumatra including 10 provinces within. For this reason, a SWOT analysis is needed to determine the best strategies that can drive economic growth. This analysis based on logics to enhance Strength and Opportunities, nevertheless at the same time could minimize weakness and overcoming Threats. The results of the position of the Cartesian diagram in this study were to diversify products / technologies both e-commerce and fintech and to carry out the results of the SWOT matrix strategy. After analyzing the SWOT matrix, the results in this study were to choose the S-T strategy, namely using strength to overcome threats.
\end{abstract}

Keywords: SWOT analysis, economic digitization, fintech, e-commerce, economic growth

\section{PENDAHULUAN}

Latar Belakang. Pandemi global yang dialami Dunia mulai menyebar sejak awal triwulan 2020, meluasnya COVID-19 hampir tidak pernah di pernah terprediksi oleh belahan Dunia manapun. Hal ini mempengaruhi sebagian besar lapangan usaha baik dalam penawaran global, permintaan dunia, serta keyakinan pelaku ekonomi. Meluasnya COVID-19 menyebabkan beberapa kegiatan usaha yang menjadi salah satu pengge- rak roda perekonomian terhenti karena adanya kebijakan pemerintah untuk membatasi kegiatan di luar tempat tinggal. Kebijakan stay at home yang membatasi kegiatan di luar rumah, hal ini mengganggu kinerja lapangan usaha yang sebagian besa rmelakukan transaksi jual beli secara fisik. Penurunan pendapatan para pelaku usaha secara langsung menyebabkan penurunan pertumbuhan ekonomi baik secara global dan maupun di setiap wilayah Indonesia 
termasuk wilayah Sumatera dengan 10 provinsi di dalamnya.

Berdasarkan data dari Bank Indonesia dalam laporan perekonomian wilayah Sumatera, Indonesia terhadap 10 provinsi di wilayah Sumatera yaitu, Sumatera Selatan, Sumatera Utara, Kepulauan Riau, Aceh, Sumatra Barat, Lampung, Bengkulu, Bangka Belitung, Jambi, dan Riau. Beberapa wilayah Sumatera mengalami penurunan ekonomi yang kemungkinan besar karena wabah COVID-19. Seperti pada wilayah Sumatera Barat penurunan terjadi kurang lebih 1,21\% (yoy) antara triwulan I 2020 yang mengalami partumbuhan ekonomi hingga 3,92\% (yoy) dibandingkan dengan triwulan sebelumnya perekonomian tumbuh pada level 5,13\% (yoy). Demikian pula dengan jika dilihat dari sisi pengeluaran, pertumbuhan ekonomi Sumatera Barat tertahan oleh realisasi konsumsi rumah tangga yang melambat sebesar $0,58 \%$ (yoy) jika pada triwulan I tahun 2020 sebasar 4,28\% (yoy) melambat dibandingkan triwulan IV 2019 dari 4,86\% (yoy).

Menurunnya pertumbuhan ekonomi dan pengeluaran pada Sumatera Barat berbanding terbalik dengan konsumsi pemerintah yang tumbuh pada triwulan I tahun 2020 mencapai 5,00\% (yoy) lebih tinggi dibandingkan dengan triwulan sebelumnya yang tumbuh 3,83\% (yoy). Peningkatan konsumsi pemerintah pada triwulan laporan didorong oleh pengeluaran bantuan sosial yang disalurkan sehubungan dengan adanya wabah COVID-19.

Untuk wilayah Sumatera Selatan juga mengalami penurunan tingkat pertumbuhan ekonomi sebesar $0,71 \%$ (yoy) antara triwulan I 2020 yang mengalami pertumbuhan ekonomi hingga $4,98 \%$ (yoy) dibandingkan dengan triwulan sebelumnya dimana perekonomian tumbuh pada level 5,69\% (yoy). Namun pada Sumatera Selatan kinerja perekonomian masih berada diatas partumbuhan ekonomi nasional dan Sumatera tercatat $2,97 \%$ (yoy) dan 3,25\% (yoy). Hal ini menempatkan Sumatera Selatan menjadi provinsi dengan pertumbuhan paling tinggi di Regional Sumatera.

Dalam laporan perekonomian Bank Indonesia diketahui bahwa persentase ratarata pertumbuhan perekonomian pada wilayah Sumatera masih diatas presentase pertumbuhan ekonomi secara nasional. Walaupun beberapa provinsi jauh dibawah presentase pertumbuhan ekonomi secara nasional, tetapi beberapa provinsi berada diatas persentase pertumbuhan ekonomi secara nasional. Hal ini menggambarkan bahwa perekonomian di wilayah Sumatera dapat tetap tumbuh karena persentase ratarata pertumbuhan ekonomi di wilayah Sumatera masih lebih tinggi daripada tingkat rata-rata pertumbuhan secara nasional dan pertumbuhan ekonomi dapat terus meningkat jika didukung oleh teknologi atau digitalisasi ekonomi yang dapat mendukung transaksi jual beli para pelaku usaha tanpa kontak fisik

Berdasarkan latar belakang yang telah di sebutkan di atas, maka peneliti memiliki tujuan penelitian yaitu mengetahui pentingnya analisa SWOT untuk menilai strategi pemulihan ekonomi yang tepat agar mendorong percepatan pemulihan ekonomi pada era new normal. Selain itu, perlu adanya pendalaman faktor-faktor yang dapat mempengaruhi pertumbuhan ekonomi, stabilitas sistem keuangan serta kesejahteraan di Sumatera, sehingga dapat menjadi dasar pengambilan kebijakan pemerintah dalam meningkatkan pertumbuhan ekonomi di Wilayah Sumatera. Tujuan lainnya adalah untuk mengetahui apakah memang ekonomi digital dalam hal ini adalah teknologi keuangan dan e-commerce dapat mendorong pertumbuhan ekonomi wilayah Sumatera 
sehingga peneliti terlebih dahulu harus memahami lingkungan usaha yang ada di wilayah Sumatera, Indonesia. Memahami lingkungan bisnis adalah inti dari sebuah strategi dan proses perencanaan, sebuah pengukuran yang dapat memfasilitasi pemahaman dengan analisis SWOT (Hill \& Westbrook, 1997). Oleh karena itu penelitian ini akan menganalisa peran digitalisasi ekonomi yaitu teknologi keuangan (Fintech), dan e-commerce terhadap partumbuhan ekonomi wilayah Sumatera dengan menggunakan analisis SWOT.

\section{TINJAUAN TEORITIS}

Proses perubahan kondisi perekonomian suatu negara secara berkesinambungan menuju keadaan yang lebih baik selama periode tertentu adalah sebuah pertumbuhan ekonomi. Pertumbuhan ekonomi juga dapat diartikan sebagai proses kenaikan kapasitas produksi suatu perekonomian yang diwujudkan dalam bentuk kenaikan pendapatan. Jika suatu wilayah mengalami pertumbuhan ekonomi maka dapat dikatakan bahwa wilayah tersebut ikut serta dalam keberhasilan pembangunan ekonomi wilayah tersebut dan pembangunan ekonomi secara menyeluruh dalam kehidupan masyarakat. Dan dalam hal ini pertumbuhan ekonomi pada wilayah Sumatera dapat di dorong oleh digitalisasi ekonomi, karena digilitalisasi ekonomi dapat mempermudah dan memperluas jangkauan transaksi perekonomian dengan adanya digitalisasi ekonomi. Untuk mengetahui seberapa besar peran digitalisasi ekonomi mempengaruhi pertumbuhan ekonomi secara global dan khususnya di wilayah Sumatera, Indonesia maka, akan dilakukan analisis SWOT terhadap strategi digitalisasi yang akan dipilih dan dijalankan. Dan dalam hal ini strategi digitalisasi ekonomi yang dipilih adalah penggunaan fintech dan $e$ commerce.

Analisa SWOT. Analisis SWOT adalah identifikasi berbagai faktor secara sistematis untuk merumuskan strategi perusahaan. Analisis ini didasarkan pada logika yang dapat memaksimalkan kekuatan (Strengths) dan peluang (Opportunities), namun secara bersamaan dapat meminimalkan kelemahan (Weakness) dan ancaman (Threats). (Samejima et al., 2006). Kekuatan dan kelemahan adalah faktor internal (terkendali) yang mendukung dan menghalangi organisasi untuk mencapai misinya masing-masing. Sedangkan peluang dan ancaman adalah faktor eksternal yang sulit di prediksi (Dyson, 2004). Dengan mengidentifikasi empat faktor ini, sebuah strategi digitalisasi ekonomi dapat dikenali perannya terhadap pertumbuhan ekonomi, karena dengan mengenali dan menganalisa keempat faktor yaitu kekuatan, kelemahan, peluang dan ancaman dari sebuah strategi yang ada maka akan didapat kompetensi untuk pengambilan keputusan, perencanaan dan pengembangan yang tepat. Sejalan dengan penjelasan dari (Rangkuti, 2004) yang mendefinisikan analisis SWOT adalah identifikasi berbagai factor secara sistematis untuk merumuskan strategi perusahaan. Analisis ini didasarkan pada logika yang dapat memaksimalkan kekuatan (strength) dan peluang (opportunity), namun secara bersamaan dapat meminimalkan kelemahan (weakness) dan ancaman (threats). Proses pengambilan keputusan strategi selalu berkaitan dengan pengembanganmisi, tujuan, strategi dan kebijakanperusahaan. Dengan demikian, perencanaan strategi harus menganalisa faktorfaktor strategi perusahaan (kekuatan, kelemahan, peluang dan ancaman) dalam kondisi yang saat ini. Analisis SWOT akan membandingkan antara faktor eksternal yaitu peluang (opportunity) dan ancaman 
(threats) dengan faktor internal yaitu kekuatan (strenght) dan kelemahan (weakness). Faktor eksternal yang mempengaruhi terbentuknya opportunities and threats ( $\mathrm{O}$ dan $\mathrm{T}$ ) antara lain adalah lingkungan industri dan lingkungan bisnis makro, ekonomi, politik, hukum, teknologi, kependudukan, dan social budaya. Sedangkan faktor internal yaitu strenghts dan weaknesses ( $\mathrm{S}$ dan W) antara lain meliputi semua macam manajemen fungsional yaitu pemasaran, keuangan, operasi, sumberdaya manusia, system informasi manajemen dan budaya perusahaan (corporate culture). Menurut (Coman \& Ronen, 2009) analisis SWOT telah dipuji karena kesederhanaannya dan telah digunakan terus digunakan sejak 1960an. Namun, dalam pelaksanaannya tidak bias menawarkan hasil yang efisien dan terkadang dapat menyebabkan kesalahan dalam pengambilan keputusan bisnis. Langkah-langkah utama dari pendekatan ini dapat diringkas sebagai berikut. Pertama, analisis SWOT dilakukan melalui diskusi internal untuk mengidentifikasi kelompok SWOT yang ada pada strategi digitalisasi ekonomi yaitu fintech dan e-commerce. Kemudian, faktor penting lainnya adalah faktor SWOT ditentukan melalui perbandingan berpasangan di dalam dan di antara kelompok SWOT. Terakhir, tingkat kepentingan faktor SWOT digabungkan berdasarkan matriks perbandingan. Analisis SWOT yang dilakukan adalah untuk menganalisa peran digitalisasi ekonomi yaitu fintech dan e-commerce sesuai kuesioner terhadap pertumbuhan ekonomi khususnya di wilayah Sumatera, Indonesia.

Matrik SWOT. Untuk menyusun faktor-faktor strategis perusahaan adalah menggunakan alat yaitu matrik SWOT. Matrik ini dapat mengambarkan secara jelas bagaimana faktor eksternal yaitu peluang dan ancaman yang dihadapi perusahaan yang disesuaikan dengan kekuatan dan kelemahan yang dimilikinya. Matrik ini dapat menghasilkan 4 kemungkinan alternative strategis. Antara lain Strategi SO (Strenghts-Opportunities), ST (StrenghtsThreats), WO (Weaknesses-Opportunities), dan WT (Weknesses-Threats). Strategi SO (Strenghts-Opportunities) yaitu dengan memanfaatkan seluruh kekuatan yang dimiliki untuk mengambil dan memanfaatkan peluang yang sebesar-besarnya. Strategi ST (Strenghts-Threats) adalah strategi dalam menggunakan kekuatan yang dimiliki perusahaan untuk mengatasi ancaman. Strategi WO (Weaknesses-Opportunities) diterapkan berdasarkan pemanfaatan peluang yang ada dengan cara meminimalkan kelemahan yang ada. Strategi WT (Weknesses-Threats) berdasarkan pada kegiatan yang bersifat defensive dan berusaha meminimalkan kelemahan yang ada serta menghindari ancaman.

Penentuan Strategi. Strategi adalah alat untuk mencapai tujuan (Rangkuti, 2004). Strategi adalah sebuah tindakan yang bersifat senantiasa meningkat, terus menerus dan dilakukan berdasarkan sudut pandang yang diharapkan oleh para pelangan di masa depan. Strategi secara eksplisit, yaitu rencana tindakan yang menerangkan tentang alokasi sumberdaya serta berbagai aktivitas untuk menghadapi lingkungan, memperoleh keunggulan bersaing, dan mencapai tujuan perusahaan (Daft et al., 2010). Keunggulan bersaing (competitive advantege) adalah hal yang membedakan satu dengan yang lain dan memberi ciri khas bagi perusahaan untuk memenuhi kebutuhan pasar konsumen. Inti perumusan strategi adalah menentukan bagaimana perusahaan kita akan berbeda dengan perusahaan lain. Strategi tentu saja berubah seiring waktu sesuai dengan kondisi lingkungan, namun agar tetap kompetitif maka strategi perusahaan seharusnya berfokus kepada pemanfaatan 
kompetensi dasar, mengembangkan sinergi, dan menciptakan nilai bagi pelanggan (Daft et al., 2010).

Digitalisasi Ekonomi. Digitalisasi ekonomi adalah kegiatan perekonomian yang merupakan salah satu kemajuan di bidang perekonomian yang menggunakan teknologi digital sebagai fungsi utama dalam melakukan kegiatan transakasinya. Sebuah sosio politik dengan system ekonomi yang memiliki suatu karakteristik dalam sebuah bagian ruang intelejen, dengan meliputi informasi, berbagai akses instrument informasi, kappasitas informasi dan pemrosesan informasi adalah merupakan bagian digital ekonomi (Doughty, 2014). Menurut (Blackman et al., 2014), untuk membentuk suatu ekonomi digital di dalam sebuah pasar yang sedang berkembang terdapat tiga elemen dasar di dalamnya yaitu :

a. Akses Internet - Dalam menjalankan aktivitas ekonomi digital, akses Internet merupakan hal paling mendasar. Akses internet ini akan menjadi penghubung antara bisnis, pemerintah dan masyarakat. Dengan adanya akses internet maka digitalisasi ekonomi akan tercipta dan menghubungkan antar pelaku usaha dengan konsumen dari semua wilayah termasuk di wilayah Sumatera.

b. Akses transaksional - Akses transaksional menjadikan suatu produk dan layanan menjadi dapat dinikmati dan dikonsumsi oleh masyarakat. Di dalam ekonomi yang berkembang, kemudahan akses transaksional menjadi sesuatu yang cukup kompleks untuk mendukung peningkatan pertumbuhan perekonomian pada suatu wilayah. Karena akses transaksional memiliki dua buah manfaat seperti membuka peluang bagi jenis bisnis baru serta kemampuan didalam mengelola transaksi yang ada dalam setiap pelaku usaha.

\section{c. Entrepreneurship-Entrepreneurship}

memegang perananan penting didalam pengembangan system teknologi digital di kalangan entrepreneur. Karena entrepreneur merupakan salah satu penggerak pertumbuhan perekonomian dengan salah satu perannya sebagai pelaku usaha.

Beberapa contoh bagian dari proses digitalisasi ekonomi adalah adanya teknologi keuangan dan e-commerce. Teknologi keuangan atau yang biasa disebut sebagai fintech adalah penggunaan teknologi di dalam dunia keuangan yang menciptakan kemudahan (Arner et al., 2015). Teknologi financial juga di sebut sebagai suatu bidang bisnis yang mengarah kepada penyedia layanan keuangan dengan perangkat lunak dan teknologi modern di dalamnya (Weekly, 2017)

E-commerce adalah bagian dari transaksi pembayaran yang diproses dan diterima secara elektronik (E-payment). Ecommerce dianggap sebagai bagian dari $e$ payment karena penyediaan fasilitas pembayaran secara elektronik dibutuhkan dalam memfasilitasi kehadiran layanan. Ecommerce merupakan suatu bentuk komitmen keuangan yang melibatkan antara pembeli dan penjual dengan difasilitasi penggunaan teknologi berbasis digital. (Abrazhevich, 2004)

Untuk mengidentifikasi dan menganalisa apakah digitalisasi ekonomi yang dalam hal ini adalah penggunaan $e$ commerce dan fintech mempengaruhi tingkat pertumbuhan ekonomi wilayah Sumatera. Dan untuk mengidentifikasi penggunaan e-commerce dan fintech di wilayah Sumatera pada penelitian ini akan menggunakan tehnik analisa SWOT yaitu tehnik yang akan menganalisa kekuatan (Strengths), peluang (Opportunities), kelemahan (Weakness) dan ancaman (Threats). 


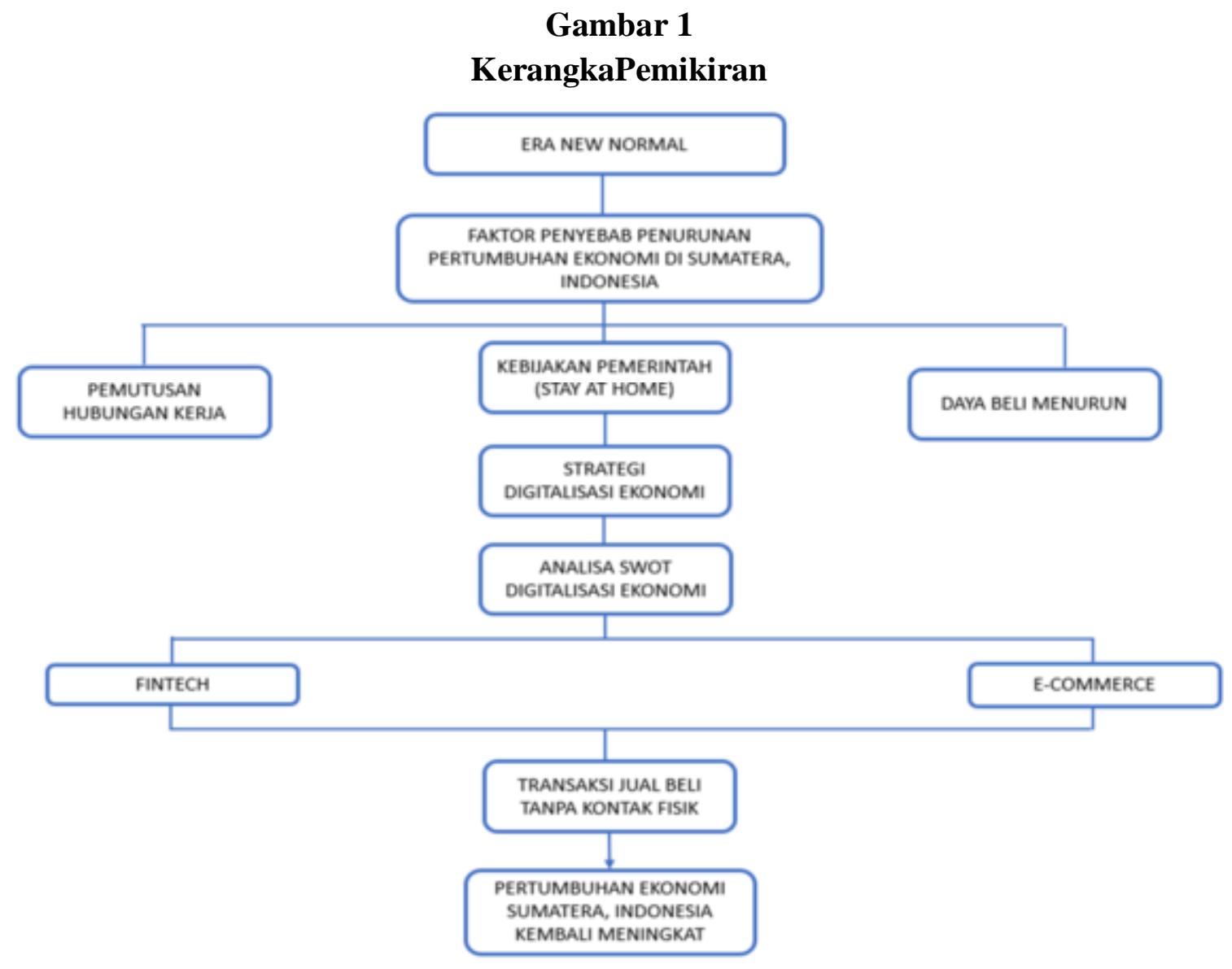

\section{METODE PENELITIAN}

Desain penelitian. Desain penelitian ini dibuat berdasarkan permasalahan penelitian yaitu mengidentifikasi peran digitalisasi ekonomi khususnya fintech dan e-commerce terhadap pertumbuhan ekonomi Indonesia khususnya di wilayah Sumatera dengan 10 provinsi di dalamnya yaitu, Sumatera Selatan, Sumatera Utara, Kepulauan Riau, Aceh, Sumatra Barat, Lampung, Bengkulu, Bangka Belitung, Jambi, dan Riau. Penelitian ini juga di desain untuk memperoleh wawasan yang mendalam terhadap permasalahan mengenai penurunan pertumbuhan ekonomi yang di sebabkan karena adanya pandemic COVID-19 yang membuat kebijakan baru dari pemerintah dalam era New Normal.

Untuk mengetahui peran fintech dan $e$ commerce terhadap pertumbuhan ekonomi di wilayah Sumatera dan untuk memperoleh wawasan mengenai dampak sebuah kebijakan pemerintah era New Normal terhadap pertumbuhan ekonomi di seluruh provinsi di Sumatera maka dalam penelitian ini digunakan teknik pengamatan tidak langsung ke lapangan tetapi mengamati dan menganalisis data sekunder yang diperoleh dari Laporan Perekonomian Bank Indonesia untuk wilayah Sumatera, wawancara mendalam (indepth interview) dengan pihak-pihak terkait melalui kuesioner online yang disebarkan secara random kepada para pelaku usaha dan konsumen yang tersebar di seluruh provinsi di wilayah Sumatera dan studi kepustakaan atau literatur.

Alat yang dipakai untuk menyusun faktor-faktor strategis adalah matrik SWOT, sedangkan metode yang dipergunakan dalam penelitian ini adalah kualitatif. 
Penelitian ini bersifat eksploratif, tujuannya untuk menformulasikan strategi partumbuhan ekonomi berdasarkan faktor internal dan eksternal yang dimiliki oleh sebuah teknologi digital ekonomi yang dalam hal ini adalah teknologi keuangan (fintech) dan e-commerce yang terdapat 10 provinsi di wilayah Sumatera.

Populasi dan Sampel. Dalam penelitian ini, sesuai dengan penelitian sebelumnya yang dilakukan oleh (Cohen, 2007) yang menyatakan bahwa semakin besar sampel dari besarnya populasi yang ada adalah semakin baik, akan tetapi ada jumlah batas minimal yang harus diambil oleh peneliti yaitu sebanyak 30 sampel. Hal ini sejalan dengan yang dikemukakan oleh (Mahmud \& Si, 2011) yang menyatakan bahwa untuk penelitian yang menggunakan analisis data statistik, ukuran sampel paling minimum adalah 30 .

Maka dalam penelitian ini mengambil sampel sebanyak 92 responden dengan pengambilan sampel secara acak (random sampling) kepada responden yang tinggal di 10 provinsi di Sumatera. 92 responden dengan proporsi adalah $65,2 \%$ pelaku usaha dan $34,8 \%$ adalah konsumen.

Teknik Pengumpulan Data. Dalam penelitian ini data dikumpulkan melalui kuisoner secara online yang di sebar ke 10 provinsi di Sumatera, Indonesia. Setiap kuesioner dapat dilengkapi dalam jangka waktu berkisar 30-40 menit. Penyebaran kuesioner dilakukan oleh tim peneliti. Setiap peneliti ikut serta dalam pembuatan pertanyaan di dalam kuesioner dan penyebaran kuesioner tersebut. Untuk kemudian hasil jawaban dari setiap responden dapat digabungkan menjadi satu dokumen dan di lakukan analisa lebih lanjut.

Kuesioner rmerupakan teknik pengumpulan data yang dilakukan dengan cara memberi seperangkat pertanyaan atau per- nyataan tertulis kepada responden untuk dijawab. Selain itu kuesioner merupakan teknik pengumpulan data yang efisien bila peneliti tahu pasti variabel yang akan diukur dan tahu apa yang bisa diharapkan dari responden (P. D. Sugiyono, 2013). Dan di Era New Normal seperti saat ini teknik pengumpulan data dengan cara menyebarkan kuesioner online adalah tehnik yang paling aman untuk responden dan juga peneliti.

Dalam penelitian ini kuesioner digunakan untuk mengumpulkan data dari pelaku usaha dan konsumen yang tersebar di 10 provinsi di Sumatera Indonesia. Aspekaspek digitalisasi ekonomi khususnya fintech dan e-commerce serta pertumbuhan ekonomi yang ditanyakan dalam kuesioner kepada para pelaku usaha dan konsumen. Pertanyaan pada kusioner meliputi penggunaan e-commerce, rata-rata omset per bulan pelaku usaha dengan menggunakan platform digital dalam penjualannya, penggunaan teknologi keuangan (fintech), lama waktu proses penggunakan platform digital untuk transaksi ekonomi, jenis e-commerce yang digunakan untuk penjualan para pelaku usaha, kemudahan menggunakan fintech, besaran omset/pendapatan para pelaku usaha ketika menggunakan sarana digital ekonomi fintech dan e-commerce. Terhadap aspekaspek tersebut dilakukan penilaian dengan mempergunakan Skala Likert, yaitu $1=$ sangat tidak baik, 2 = tidak baik, 3 = kurang baik, 4 = baik, dan $5=$ sangat baik, dan dilakukan analisa terhadap jawaban responden dari pertanyaan yang bersifat pilihan berganda (multiple choice).

Sumber Data. Data yang dipergunakan dalam penelitian ini berasal dari dua sumber yaitu sumber data primer dan sumber data sekunder. Sumber data primer adalah informasi yang bersumber dari hasil kuesioner yang dilakukan kepada para pelaku usaha 
dan konsumen di wilayah Sumatera pada 10 provinsi yaitu Sumatera Selatan, Sumatera Utara, Kepulauan Riau, Aceh, Sumatra Barat, Lampung, Bengkulu, Bangka Belitung, Jambi, dan Riau. Survei dilakukan dengan menggunakan kuesioner secara online yang di sebarkan secara online melalui google form dan disebar secara random kepada para pelaku usaha dan konsumen di 10 provinsi di wilayah Sumatera.

Sumber data sekunder adalah sumbersumber lain yang menunjang penelitian ini yaitu dari buku-buku teks, majalah, jurnal atau hasil-hasil penelitian dari berbagai pihak yang relevan dengan penelitian ini. Data sekunder diperoleh dari Laporan Perekonomian Bank Indonesia, data statistik yang diperoleh dari Badan Pusat Statistik untuk wilayah Sumatera dengan 10 provinsi di dalamnya.

Teknik PengujianKualitas Data. Data yang diperoleh bias menjadi tidak berguna karena kuesioner sebagai alat pengumpul data yang nantinya data tersebut diolah untuk menghasilkan informasi tertentu, ternyata tidak memiliki validitas dan realibilitas yang tinggi. Oleh karena itu agar data penelitian ini betul-betul menggambarkan fenomena yang diukur serta hasilnya dapat dipertanggung jawabkan secara ilmiah, maka untuk menguji kuesioner dalam penelitian ini dilakukan uji validitas dan realibilitas.

Teknik Analisis Data. Menurut (M. P. P. Sugiyono \& Kuantitatif, 2009) analisis data adalah proses mencari dan menyusun data yang diperoleh dari hasil wawancara, catatan lapangan dan bahan-bahan lain secara sistematis sehingga mudah dipahami dan temuannya dapat diinformasikan kepada orang lain. Teknik analisis data dalam penelitian ini menggunakan analisis deskriptif kualitatif dan analisis SWOT. Tabel SWOT yang ada dibangun berdasarkan ide-ide utama yang berkaitan dengan digitalisasi ekonomi, tingkat pertumbuhan ekonomi, teknologi keuangan (fintech), dan $e$ commerce.

Analisis dalam penelitian meliputi analisis internal dan eksternal, dilanjutkan dengan analisis SWOT dan AHP, untuk merumuskan dan menetapkan strategi digitalisasi ekonomi khususnya penggunaan fintech dan e-commerce pada pertumbuhan ekonomi di Sumatera, Indonesia. Pengolahan data dilakukan selama dan setelah pengumpulan data.

Analisis SWOT. Analisis SWOT adalah sebagai alat formulasi strategi berbagai factor secara sistematis untuk merumuskan strategi dari sebuah penelitian. Analisis ini didasarkan pada logika yang dapat memaksimalkan kekuatan (strenngths) dan peluang (opportunities), namun secara bersamaan dapat meminimalkan kelemahan (weaknesses) dan ancaman (threats) (Rangkuti, 2019).

Proses pengambilan keputusan strategis selalu berkaitan dengan peran digitalisasi ekonomi dan dampak kebijakan pemerintah di era New Normal terhadap pertumbuhan ekonomi di wilayah Sumatera. Dengan demikian, rencana strategis yang berupa pengembangan digitalisasi ekonomi khususnya fintech dan e-commerce di Sumatera sebagai sarana untuk meningkatkan partumbuhan ekonomi di era New Normal yang terdampak dari pandemic COVID-19 harus menganalisis faktor-faktor strategis yang berkaitan dengan kekuatan, kelemahan, peluang dan ancaman berdasarkan kondisi saat ini. Hal ini dikenal sebagai analisis situasi, sedangkan model yang paling popular digunakan untuk analisis situasi adalah analisis SWOT.

Data yang dikumpulkan, diolah, dan dianalisis secara deskriptif dengan mengadopsi dan mengadaptasi model analisis 
SWOT yang merupakan analisis kualitatif dengan mengkaji factor-faktor internal dan eksternal. Faktor internal dalam hal ini adalah strengths (kekuatan atau potensi) dan weaknesses (kelemahan dan kendala). Faktor eksternal terdiri dari opportunities (peluang) dan treaths (ancaman). Analisis SWOT digunakan untuk memperoleh informasi terkait strategi digitalisasi ekonomi khususnya fintech dan e-commerce sebagai sarana untuk meningkatkan partumbuhan ekonomi di era New Normal yang terdampak dari pandemic COVID-19 di Sumatera, Indonesia. Adapun matriks analisis SWOT adalah seperti pada Tabel 3.

Tabel 3

Matrik Analisis SWOT

\begin{tabular}{lll}
\hline IFAS & Kekuatan/Strengths $(\mathbf{S})$ & Kelemahan/Weaknesses(W) \\
EFAS & Faktor-faktorkekuatan & Faktor-faktorkelemahan \\
& internal & internal \\
\hline Opportunities $(\mathbf{O})$ & Strategi SO & Strategi WO \\
Faktor- & Ciptakan strategi yang & Ciptakan strategi yang \\
faktorpeluangeksternal & menggunakankekuatanuntu & meminimalkankelemahanunt \\
& kmemanfaatkanpeluang & ukmemanfaatkanpeluang \\
\hline Threats (T) & Strategi ST & Strategi WT \\
Faktor- & Ciptakan strategi yang & Ciptakan strategi yang \\
faktorancamaneksternal & menggunakankekuatanuntu & meminimalkankelemahan \\
& kmengatasiancaman & dan menghindariancaman \\
\hline
\end{tabular}

\section{HASIL DAN PEMBAHASAN}

Statistik Deskriptif. Pada penelitian ini menggunakan data primer dengan jumlah responden sebanyak 92 orang dengan criteria sebagai berikut:

a. Kriteria responden dengan proporsi adalah $65,2 \%$ pelaku usaha dan $34,8 \%$ adalah konsumen.

b. Domisili responden $71,9 \%$ berasal dari provinsi Lampung, 12,5\% berasal dari provinsi Kepulauan Bangka Belitung, 9,4\% berasal dari Sumatera Barat, dan $6,7 \%$ dari 7 provinsi lainnya yaitu Sumatera Selatan, Sumatera Utara, Kepulauan Riau, Aceh, Bengkulu, Jambi, dan Riau.

c. Pendapatan/Omset per bulan para pelaku usaha dengan proporsi $53,1 \%$ memiliki omset dibawah Rp. 10.000.000, 31,3\% memiliki omset diantara Rp.10.000.000Rp. 20.000.000, sisanya sebesar $15,6 \%$ memiliki omset diatas Rp. 20.000.000.

d. Banyaknya penggunaan media digital sebagai transaksi jual/beli adalah dengan proporsi $81,3 \%$ adalah dibawah 100 kali transaksi per bulan dan sisanya sebanyak $18,7 \%$ memiliki transaksi dengan penggunaan media digital fintech atau $e$ commerce diatas 100 kali transaksi per bulan.

e. Proporsi penggunaan media digital untuk transaksi penjualan adalah $70 \%$ melalui e-commerce dan $30 \%$ lainnya menggunakan berbagai media sosial.

f. Pemakaian teknologi keuangan untuk metode pembayaran yang digunakan adalah dengan proporsi $83,3 \%$ adalah melalui transfer dan $16,7 \%$ menggunakan metode pembayaran lainnya. 
Demografi Responden. Sumber data primer pada penelitian ini adalah hasil kuesioner yang dilakukan kepada para pelaku usaha dan konsumen di wilayah Sumatera pada 10 provinsi yaitu Sumatera Selatan, Sumatera Utara, Kepulauan Riau, Aceh, Sumatra Barat, Lampung, Bengkulu, Bangka Belitung, Jambi, dan Riau. Dari 10 provisnsi di wilayah Sumatera penelitian ini mengambil sampel sebanyak 92 responden. 92 responden dengan proporsi $75 \%$ adalah berjenis kelamin laki-laki $25 \%$ berjenis kelamin perempunan, dengan kategori $65,2 \%$ pelaku usaha dan $34,8 \%$ adalah konsumen, dan dengan proporsi daerah asal responden terbesar adalah di provinsi Lampung, Sumatera sebesar 71,9\%.

Uji Kualitas Data. Teknik pengumpulan dalam penelitian ini data diperoleh dari data sekunder yaitu laporan Perekonomian Bank Indonesia untuk wilaya Sumatera, observasi, dan kuesioner. Untuk membuat langkah awal analisis SWOT serta mengambil keputusan, teknik pengumpulan data ini menggunakan pengumpulan data kuesioner sebanyak 92 responden, yang membentuk dari masing-masing variabel SWOT. Tabel dibawah adalah indikator yang diberikan kepada responden yang membentuk variabel SWOT.

Tabel 2

Pernyataan Kuesioner Faktor Internal

\begin{tabular}{|c|c|c|c|}
\hline No & Kekuatan & No & Kelemahan \\
\hline S1 & $\begin{array}{l}\text { Produk yang di } \\
\text { butuhkandapatditemukandenganmudah pada } \\
\text { layanan e-commerce }\end{array}$ & W1 & $\begin{array}{l}\text { TeknologiKeuangan (fintech) } \\
\text { masihbelumdikenalsecaraluas }\end{array}$ \\
\hline $\mathrm{S} 2$ & Produk fintech dapatditemukandenganmudah & W2 & $\begin{array}{l}\text { E-commerce } \\
\text { masihbelumdikenalsecaraluas }\end{array}$ \\
\hline S3 & $\begin{array}{l}\text { Kemudahanmenggunakanteknologikeuangan } \\
\text { (fintech) dan layanan e-commerce }\end{array}$ & W3 & $\begin{array}{l}\text { Kepercayaanpenggunauntukkeamanan } \\
\text { dalammenggunakan } \text {-commerce yang } \\
\text { masihrendah }\end{array}$ \\
\hline S4 & KemudahanAkses e-commerce dan fintech & W4 & $\begin{array}{l}\text { Kepercayaanpenggunauntukkeamanan } \\
\text { dalamteknologikeuangan (fintech) yang } \\
\text { masihrendah }\end{array}$ \\
\hline S5 & $\begin{array}{l}\text { Kecepatanpemberianinformasiproduk yang } \\
\text { dibutuhkanbaikdalamlayanan e-commerce } \\
\text { dan teknologikeuangan (fintech) }\end{array}$ & W5 & $\begin{array}{l}\text { Jaringan internet yang belumstabil dan } \\
\text { merata di seluruh wilayah Indonesia }\end{array}$ \\
\hline S6 & $\begin{array}{l}\text { Strukturinformasi yang diberikane-commerce } \\
\text { dan fintechmudahdipahami }\end{array}$ & & \\
\hline S7 & $\begin{array}{l}\text { Penggunaan media e-commerce dan fintech } \\
\text { dapatmengefisiensiwaktu yang di butuhkan }\end{array}$ & & \\
\hline S8 & $\begin{array}{l}\text { Penggunaan media e-commerce dan fintech } \\
\text { dapatmengefisiensibiaya yang di butuhkan }\end{array}$ & & \\
\hline S9 & $\begin{array}{l}\text { Kepuasankonsumensaatpenggunaanteknologi } \\
\text { keuangan (fintech) dan } \text { e-commerce }\end{array}$ & & \\
\hline S10 & $\begin{array}{l}\text { Keinginanmerekomendasikan fintech dan e- } \\
\text { commerce kepadapihak lain }\end{array}$ & & \\
\hline
\end{tabular}


Pemberian nilai rating pada table pernyataan didasarkan pada keterangan sebagai berikut : Skala 1 = Apabila responden sangat tidak setuju dengan pernyataan tersebut

Skala 2 = Apabila responden tidak setuju dengan pernyataan tersebut

Skala 3 = Apabila responden netral dengan pernyataan tersebut

Skala 4 = Apabila responden setuju dengan pernyataan tersebut

Skala 5 = Apabila responden sangat setuju dengan pernyataan tersebut
Uji Validitas. Uji validitas yaitu untuk menentukan apakah data responden dinyatakan valid atau tidak valid, sedangkan reliabilitas yaitu hasil pengukuran yang dapat dipercaya. Uji validitas dan reliabilitas dengan jumlah sampel 92, nilai $r$ table sebesar 0,1726. Rumus menghitung $r$ tabel $=$ $\mathrm{N}-2$ dengan $\mathrm{N}$ jumlah sampel, maka $\mathrm{r}$ tabel $=92-2=90$. Dilihat dari $\mathrm{r}$ table dengan taraf signifikan 5\%, maka $\mathrm{r}$ tabel $=0,1726$. Hasil uji validitas dapat dilihat pada Tabel 4.

Tabel 3

PernyataanKuesionerFaktorEksternal

\begin{tabular}{llll}
\hline No & \multicolumn{1}{c}{ Peluang } & No & \multicolumn{1}{c}{ Ancaman } \\
\hline O1 & Perubahan gaya hidup masyarakat saat ini. & T1 & Krisis ekonomi global. \\
\hline O2 & $\begin{array}{l}\text { Kemajuan teknologi yang berkembang saat } \\
\text { ini. }\end{array}$ & T2 & $\begin{array}{l}\text { Tingkat kejahatan cyber (cybercrime) } \\
\text { semakin tinggi }\end{array}$ \\
\hline O3 & Tingginya tingkat kegiatan bisnis. & T3 & Pandemi COVID-19 yang belum selesai \\
\hline O4 & Kegiatanbisnis yang makinluas. & & \\
\hline O5 & Hubungan dengan pemasok yang baik. & & \\
\hline O6 & Pangsa pasar cukup tinggi saat ini. & & \\
\hline
\end{tabular}

Tabel 4

Rangkuman Hasil Uji Validitas

\begin{tabular}{llccc}
\hline $\begin{array}{c}\text { No. Soal } \\
\text { Pernyataan }\end{array}$ & \multicolumn{1}{c}{ Pertanyaan } & $\begin{array}{c}\text { r- } \\
\text { hitung }\end{array}$ & $\begin{array}{c}\text { r- } \\
\text { tabel }\end{array}$ & Ket. \\
\hline S1 & $\begin{array}{l}\text { Produk yang di butuhkan dapat ditemukan dengan } \\
\text { mudah pada layanan e-commerce }\end{array}$ & 1 & 0,1726 & Valid \\
\hline S2 & Produk fintech dapat ditemukan dengan mudah & 0,1 & 0,1726 & Tidak Valid \\
\hline S3 & $\begin{array}{l}\text { Kemudahan menggunakan teknologi keuangan } \\
\text { (fintech) dan layanan e-commerce }\end{array}$ & 0,422 & 0,1726 & Valid \\
\hline S4 & Kemudahan Akses e-commerce dan fintech & 0,35 & 0,1726 & Valid \\
\hline S5 & $\begin{array}{l}\text { Kecepatan pemberian informasi produk yang } \\
\text { dibutuhkan baik dalam layanan e-commerce dan } \\
\text { teknologi keuangan }(\text { fintech })\end{array}$ & 0,364 & 0,1726 & Valid \\
\hline S6 & $\begin{array}{l}\text { Struktur informasi yang diberikan } \text { e-commerce dan } \\
\text { fintech mudah dipahami }\end{array}$ & 0,474 & 0,1726 & Valid \\
\hline S7 & $\begin{array}{l}\text { Penggunaan media } \text {-commerce dan fintech dapat } \\
\text { mengefisiensi waktu yang di butuhkan }\end{array}$ & 0,341 & 0,1726 & Valid \\
\hline S8 & $\begin{array}{l}\text { Penggunaan media } e \text {-commerce dan fintech dapat } \\
\text { mengefisiensi biaya yang di butuhkan }\end{array}$ & 0,205 & 0,1726 & Valid \\
\hline
\end{tabular}




\begin{tabular}{llccc}
\hline $\begin{array}{c}\text { No. Soal } \\
\text { Pernyataan }\end{array}$ & \multicolumn{1}{c}{ Pertanyaan } & $\begin{array}{c}\text { r- } \\
\text { hitung }\end{array}$ & $\begin{array}{c}\text { r- } \\
\text { tabel }\end{array}$ & Ket. \\
\hline S9 & $\begin{array}{l}\text { Kepuasan konsumen saat penggunaan teknologi } \\
\text { keuangan }(\text { fintech) dan } \text { e-commerce }\end{array}$ & 0,265 & 0,1726 & Valid \\
\hline S10 & $\begin{array}{l}\text { Keinginan merekomendasikan fintech dan e- } \\
\text { commerce kepada pihak lain }\end{array}$ & 0,282 & 0,1726 & Valid \\
\hline W1 & $\begin{array}{l}\text { Teknologi Keuangan (fintech) masih belum dikenal } \\
\text { secara luas }\end{array}$ & 0,244 & 0,1726 & Valid \\
\hline W2 & E-commerce masih belum dikenal secara luas & 0,257 & 0,1726 & Valid \\
\hline W3 & $\begin{array}{l}\text { Kepercayaan pengguna untuk keamanan dalam } \\
\text { menggunakan } \text { e-commerce yang masih rendah }\end{array}$ & 0,187 & 0,1726 & Valid \\
\hline W4 & $\begin{array}{l}\text { Kepercayaan pengguna untuk keamanan dalam } \\
\text { teknologi keuangan (fintech) yang masih rendah }\end{array}$ & 0,24 & 0,1726 & Valid \\
\hline W5 & $\begin{array}{l}\text { Jaringan internet yang belum stabil dan merata di } \\
\text { seluruh wilayah Indonesia }\end{array}$ & $-0,022$ & 0,1726 & Tidak Valid \\
\hline O1 & Perubahan gaya hidup masyarakat saat ini. & 0,262 & 0,1726 & Valid \\
\hline O2 & Kemajuan teknologi yang berkembang saat ini. & 0,474 & 0,1726 & Valid \\
\hline O3 & Tingginya tingkat kegiatan bisnis. & $-0,094$ & 0,1726 & Tidak Valid \\
\hline O4 & Kegiatan bisnis yang makin luas. & 0,118 & 0,1726 & Tidak Valid \\
\hline O5 & Hubungan dengan pemasok yang baik. & 0,143 & 0,1726 & Tidak Valid \\
\hline O6 & Pangsa pasar cukup tinggi saat ini. & 0,144 & 0,1726 & Tidak Valid \\
\hline T1 & Krisis ekonomi global. & 0,343 & 0,1726 & Valid \\
\hline T2 & Tingkat kejahatan cyber (cybercrime) semakin tinggi & 0,084 & 0,1726 & Tidak Valid \\
\hline T3 & Pandemi COVID-19 yang belum selesai & 0,453 & 0,1726 & Valid \\
\hline
\end{tabular}

Dilihat dari table 3 ada beberapa pernyataan yang tidak valid, yaitu soal no S2, W5, O3, O4, O5, O6 dan T2. Maka, 7 pernyataan tersebut tidak digunakan lagi keperhitugan selanjutnya karena dinyatakan tidak valid.

Uji Reliabilitas. Untuk mengetahui apakah suatu instrument yang digunakan didalam kuisioner dapat dihandalkan dan merupakan informasi konsisten dari waktu ke waktu dan dapat dipercaya sebagai alat pengumpulan data, maka perlu dilakukan uji reliabilitas terhadap informasi yang tersedia yang merupakan jawaban dari para responden. Suatu kuesioner dikatakan reliable atau handal jika jawaban seseorang terhadap pernyataan konsisten dari waktu ke waktu.

Dari table 5 dapat di simpulkan bahwa uji reliabilitas diperoleh nilai Cronbach's Alpha sebesar 0.817 atau $81.7 \%$. Menurut kriteria, apabila nilai Cronbach's Alpha lebih besar dari 60\%, maka kuesioner atau indicator tersebut dianyatakan reliabel. Sehingga, tabel diatas menunjukkan bahwa nilai Cronbach's Alpha sebesar 81.7\% > $60 \%$ dinyatakan reliabel. Setelah dilakukan uji validitas dan uji reliabilitas maka selanjutnya adalah menghitung jawaban pada setiap rating yang dalam penelitian ini menggunakan skala likert 1-5. Berikut adalah data hasil kuisioner dan pemberian rating dari faktor internal dan eksternal. 
Tabel 5

Reliabilitas Statistik

\begin{tabular}{c|c}
\hline Cronbach's Alpha & N of Items \\
\hline .817 & 24 \\
\hline
\end{tabular}

Tabel 6

Data Hasil Kuesioner dan Pemberian Rating Dari Faktor Internal

\begin{tabular}{|c|c|c|c|c|c|c|}
\hline \multirow{2}{*}{ No } & \multirow{2}{*}{ Kekuatan } & \multicolumn{5}{|c|}{ Rating } \\
\hline & & 1 & 2 & 3 & 4 & 5 \\
\hline 1 & $\begin{array}{l}\text { Produk yang di butuhkan dapat ditemukan dengan mudah pada } \\
\text { layanan e-commerce }\end{array}$ & 1 & 1 & 7 & 23 & 60 \\
\hline 2 & $\begin{array}{l}\text { Kemudahan menggunakan teknologi keuangan (fintech) dan } \\
\text { layanan e-commerce }\end{array}$ & 0 & 1 & 7 & 30 & 54 \\
\hline 3 & Kemudahan Akses e-commerce dan fintech & 1 & 0 & 8 & 27 & 56 \\
\hline 4 & $\begin{array}{l}\text { Kecepatan pemberian informasi produk yang dibutuhkan baik } \\
\text { dalam layanan e-commerce dan teknologi keuangan (fintech) }\end{array}$ & 0 & 2 & 16 & 36 & 38 \\
\hline 5 & $\begin{array}{l}\text { Struktur informasi yang diberikan e-commerce dan fintech mudah } \\
\text { dipahami }\end{array}$ & 0 & 2 & 15 & 45 & 30 \\
\hline 6 & $\begin{array}{l}\text { Penggunaan media e-commerce dan fintech dapat mengefisiensi } \\
\text { waktu yang di butuhkan }\end{array}$ & 1 & 2 & 15 & 47 & 27 \\
\hline 7 & $\begin{array}{l}\text { Penggunaan media e-commerce dan fintech dapat mengefisiensi } \\
\text { biaya yang di butuhkan }\end{array}$ & 1 & 6 & 21 & 40 & 24 \\
\hline 8 & $\begin{array}{l}\text { Kepuasankonsumensaatpenggunaanteknologikeuangan (fintech) } \\
\text { dan } e \text {-commerce }\end{array}$ & 0 & 2 & 31 & 36 & 23 \\
\hline 9 & $\begin{array}{l}\text { Keinginanmerekomendasikan fintech dan e-commerce } \\
\text { kepadapihak lain }\end{array}$ & 0 & 2 & 31 & 36 & 23 \\
\hline \multirow{2}{*}{ No } & Kelemahan & \multicolumn{5}{|c|}{ Rating } \\
\hline & & 1 & 2 & 3 & 4 & 5 \\
\hline 1 & Teknologi Keuangan (fintech) masih belum dikenal secara luas & 0 & 3 & 21 & 41 & 27 \\
\hline 2 & E-commerce masih belum dikenal secara luas & 0 & 2 & 26 & 42 & 22 \\
\hline 3 & $\begin{array}{l}\text { Kepercayaan pengguna untuk keamanan dalam menggunakan } e \text { - } \\
\text { commerce yang masih rendah }\end{array}$ & 3 & 7 & 31 & 32 & 19 \\
\hline 4 & $\begin{array}{l}\text { Kepercayaan pengguna untuk keamanan dalam teknologi } \\
\text { keuangan (fintech) yang masih rendah }\end{array}$ & 4 & 7 & 26 & 29 & 26 \\
\hline
\end{tabular}

\section{Tabel 7}

Lanjutan Data Hasil Kuesioner dan Pemberian Rating Dari FaktorEksternal

\begin{tabular}{clcccccc}
\hline \multirow{2}{*}{ No } & \multirow{2}{*}{ Peluang } & \multicolumn{5}{c}{ Rating } \\
\cline { 3 - 7 } & Perubahangayahidupmasyarakatsaatini. & $\mathbf{1}$ & $\mathbf{2}$ & $\mathbf{3}$ & $\mathbf{4}$ & $\mathbf{5}$ \\
\hline 1 & Kemajuanteknologi yang berkembangsaatini. & 0 & 2 & 20 & 46 & 24 \\
\hline \multirow{2}{*}{ No Ancaman } & & & & \multicolumn{3}{c}{ Rating } \\
\cline { 3 - 7 } & & $\mathbf{1}$ & $\mathbf{2}$ & $\mathbf{3}$ & $\mathbf{4}$ & $\mathbf{5}$ \\
\hline 1 & Krisisekonomi global. & 0 & 0 & 7 & 25 & 60 \\
\hline 2 & PandemiCOVID-19 yang belumselesai & 0 & 1 & 5 & 31 & 55 \\
\hline
\end{tabular}




\section{Tabel 8}

Perhitungan Bobot Faktor Internal

\begin{tabular}{clcr}
\hline No & \multicolumn{1}{c}{ Kekuatan } & $\begin{array}{c}\text { Pengolahan } \\
\text { Data kuisioner }\end{array}$ & Bobot \\
\hline 1 & Produk yang di butuhkandapatditemukandenganmudah pada layanan e-commerce & 416 & 0,086 \\
\hline 2 & Kemudahanmenggunakanteknologikeuangan $($ fintech) dan layanan e-commerce & 413 & 0,085 \\
\hline 3 & KemudahanAkses e-commerce dan fintech & 413 & 0,085 \\
\hline 4 & $\begin{array}{l}\text { Kecepatanpemberianinformasiproduk yang dibutuhkanbaikdalamlayanan e- } \\
\text { commerce dan teknologikeuangan }(\text { fintech) }\end{array}$ & 386 & 0,080 \\
\hline 5 & Strukturinformasi yang diberikane-commerce dan fintechmudahdipahami & 379 & 0,078 \\
\hline 6 & $\begin{array}{l}\text { Penggunaan media } \text { e-commerce dan fintech dapatmengefisiensiwaktu yang di } \\
\text { butuhkan }\end{array}$ & 373 & 0,077 \\
\hline 7 & $\begin{array}{l}\text { Penggunaan media } \text {-commerce dan fintech dapatmengefisiensibiaya yang di } \\
\text { butuhkan }\end{array}$ & 356 & 0,073 \\
\hline 8 & Kepuasankonsumensaatpenggunaanteknologikeuangan $($ fintech) dan $e$-commerce & 356 & 0,073 \\
\hline 9 & Keinginanmerekomendasikan fintech dan e-commerce kepadapihak lain & 356 & 0,073 \\
\hline Total Kekuatan & $\mathbf{3 . 4 4 8}$ & $\mathbf{0 , 7 1 1}$ \\
\hline No & Kelemahan & 368 & 0,076 \\
\hline 1 & Teknologi Keuangan (fintech) masih belum dikenal secara luas & 360 & 0,074 \\
\hline 2 & E-commerce masih belum dikenal secara luas & 333 & 0,069 \\
\hline 3 & $\begin{array}{l}\text { Kepercayaan penggunauntuk keamanan dalam menggunakan } e \text {-commerce yang } \\
\text { masih rendah }\end{array}$ & 342 & 0,071 \\
\hline 4 & $\begin{array}{l}\text { Kepercayaan pengguna untuk keamanan dalam teknologi keuangan }(\text { fintech) yang } \\
\text { masih rendah }\end{array}$ & $\mathbf{1 . 4 0 3}$ & $\mathbf{0 , 2 8 9}$ \\
\hline Total Kelemahan & $\mathbf{4 . 8 5 1}$ & $\mathbf{1}$ \\
\hline Total Faktor Internal &
\end{tabular}

Perhitungan Bobot Faktor Internal. Faktor internal yang berasal dari dalam lingkungan perusahaan berupa kekuatan dan kelemahan yang kemudian perhitungan bobot ditentukan berdasarkan tingkat kepentingan atau penanganan mulai dari skala 0,00 (tidak penting) sampai 1,00 (sangat penting) dan dimana bobot tersebut dijumlahkan tidak melebihi skor total 1.00. Berikut adalah table perhitungan bobot faktor internal.

Bobot untuk faktor internal didapatkan dari menjumlahkan setiap rating pada setiap pertanyaan kemudian membagi dengan total pengolahan data faktor internal kuisioner.

Perhitungan Bobot Faktor Eksternal. Pada perhitungan bobot faktor eksternal yang berasal dari luar lingkungan perusahaan ditentukan berdasarkan tingkat kepentingan atau penanganan mulai dari skala
0,00 (tidak penting) sampai 1,00 (sangat penting) dan dimana bobot tersebut dijumlahkan tidak melebihi skor total 1.00. Berikut adalah table hasil perhitungan bobot faktor eksternal.

Bobot untuk faktor eksternal didapatkan dari menjumlahkan setiap rating pada setiap pertanyaan kemudian membagi dengan total pengolahan data faktor eksternal kuisioner.

\section{Perhitungan Matriks Internal Strate-} gic Factors Analysis Summary (IFAS). Perhitungan matrik IFAS merupakan perhitungan untuk menentukan bobot, rating dan skor dimana jumlah bobot tidak melebihi jumlah 1,00, dan menghitung nilai rating masing-masing faktor dengan memberikan skala 1 (tidak setuju) sampai dengan 5 sangat setuju. Berikut adalah table hasil perhitungan matrik IFAS. 
Tabel 9

Perhitungan Bobot Faktor Eksternal

\begin{tabular}{clrr}
\hline No & Peluang & $\begin{array}{r}\text { Pengolahan } \\
\text { Data kuisioner }\end{array}$ & \multicolumn{1}{c}{ Bobot } \\
\hline 1 & Perubahangayahidupmasyarakatsaatini. & 368 & 0,232 \\
\hline 2 & Kemajuanteknologi yang berkembangsaatini. & 379 & 0,239 \\
\hline Total Peluang & $\mathbf{2 . 2 1 9}$ & $\mathbf{0 , 4 7 2}$ \\
\hline No & Ancaman & & \\
\hline 1 & Krisisekonomi global. & 421 & 0,266 \\
\hline 2 & PandemiCOVID-19 yang belumselesai & 416 & 0,263 \\
\hline Total Ancaman & $\mathbf{8 3 7}$ & $\mathbf{0 , 5 2 8}$ \\
\hline Total FaktorEksternal & $\mathbf{1 . 5 8 4}$ & $\mathbf{1}$ \\
\hline
\end{tabular}

Tabel 10

Perhitungan Matrik Internal Strategic Factor Analisis Summary (IFAS)

\begin{tabular}{|c|c|c|c|c|}
\hline No & Kekuatan & Bobot & Rating & Skor \\
\hline 1 & $\begin{array}{l}\text { Produk yang di butuhkan dapat ditemukan dengan mudah pada layanan e- } \\
\text { commerce }\end{array}$ & 0,086 & 4,5 & 0,39 \\
\hline 2 & $\begin{array}{l}\text { Kemudahan menggunakan teknologi keuangan (fintech) dan layanan e- } \\
\text { commerce }\end{array}$ & 0,085 & 4,5 & 0,38 \\
\hline 3 & Kemudahan Akses e-commerce dan fintech & 0,085 & 4,5 & 0,38 \\
\hline 4 & $\begin{array}{l}\text { Kecepatan pemberian informasi produk yang dibutuhkan baik dalam } \\
\text { layanan e-commerce dan teknologi keuangan (fintech) }\end{array}$ & 0,080 & 4,2 & 0,33 \\
\hline 5 & $\begin{array}{l}\text { Struktur informasi yang diberikan e-commerce dan fintech mudah } \\
\text { dipahami }\end{array}$ & 0,078 & 4,1 & 0,32 \\
\hline 6 & $\begin{array}{l}\text { Penggunaan media e-commerce dan fintech dapatmengefisiensiwaktu } \\
\text { yang di butuhkan }\end{array}$ & 0,077 & 4,1 & 0,31 \\
\hline 7 & $\begin{array}{l}\text { Penggunaan media } e \text {-commerce dan fintech dapat mengefisiensi biaya } \\
\text { yang di butuhkan }\end{array}$ & 0,073 & 3,9 & 0,28 \\
\hline 8 & $\begin{array}{l}\text { Kepuasan konsumen saat penggunaan teknologi keuangan (fintech) dan } e \text { - } \\
\text { commerce }\end{array}$ & 0,073 & 3,9 & 0,28 \\
\hline 9 & Keinginan merekomendasikan fintech dan e-commerce kepada pihak lain & 0,073 & 3,9 & 0,28 \\
\hline \multicolumn{2}{|c|}{ Total Kekuatan } & $\mathbf{0 , 7 1 1}$ & 37,5 & 2,972 \\
\hline No & Kelemahan & & & \\
\hline W1 & Teknologi Keuangan (fintech) masih belum dikenal secara luas & 0,076 & 4,0 & 0,30 \\
\hline W2 & E-commerce masih belum dikenal secara luas & 0,074 & 3,9 & 0,29 \\
\hline W3 & $\begin{array}{l}\text { Kepercayaan pengguna untuk keamanan dalam menggunakan } e \text { - } \\
\text { commerce yang masih rendah }\end{array}$ & 0,069 & 3,6 & 0,25 \\
\hline W4 & $\begin{array}{l}\text { Kepercayaan pengguna untuk keamanan dalam teknologi keuangan } \\
\text { (fintech) yang masih rendah }\end{array}$ & 0,071 & 3,7 & 0,26 \\
\hline \multicolumn{2}{|c|}{ Total Kelemahan } & $\mathbf{0 , 2 8 9}$ & 15,3 & 1,104 \\
\hline \multicolumn{2}{|c|}{ Total Faktor Internal (IFAS) } & 1 & 52,7 & 4,076 \\
\hline
\end{tabular}

Bobot untuk faktor internal didapatkan dari menjumlahkan setiap rating pada setiap pertanyaan kemudian membagi dengan total pengolahan data faktor internal kuisioner. Perhitungan rating untuk faktor peluang kekuatan didapat dari total jumlah rating jawaban responden dibagi dengan jumlah responden. Dan perhitungan skor untuk faktor kekuatan didapat dari perkalian bobot dan rating. 
Tabel 11

Perhitungan Matrik Eksternal Strategic Factor Analisis Summary (EFAS)

\begin{tabular}{clrrr}
\hline No & Peluang & Bobot & \multicolumn{1}{l}{ Rating } & \multicolumn{1}{l}{ Skor } \\
\hline 1 & Perubahangayahidupmasyarakatsaatini. & 0,232 & 4,0 & 0,93 \\
\hline 2 & Kemajuanteknologi yang berkembangsaatini. & 0,239 & 4,1 & 0,99 \\
\hline Total Peluang & $\mathbf{0 , 4 7 2}$ & $\mathbf{8 , 1}$ & $\mathbf{1 , 9 1 5}$ \\
\hline No & Ancaman & & & \\
\hline $1 \quad$ Krisisekonomi global. & 0,266 & 4,6 & 1,22 \\
\hline $2 \quad$ PandemiCOVID-19 yang belumselesai & 0,263 & 4,5 & 1,19 \\
\hline Total Ancaman & $\mathbf{0 , 5 2 8}$ & $\mathbf{9 , 1}$ & $\mathbf{2 , 4 0 4}$ \\
\hline Total FaktorEksternal (EFAS) & $\mathbf{1}$ & $\mathbf{1 7 , 2}$ & $\mathbf{4 , 3 1 9}$ \\
\hline
\end{tabular}

Perhitungan Matriks Eksternal Strategic Factors Analysis Summary (EFAS). Perhitungan matrik EFAS sama halnya dengan matrik IFAS yaitu untuk menentukan bobot, rating dan skor dimana jumlah bobot tidak melebihi jumlah 1,00, dan menghitung nilai rating masing-masing factor dengan memberikan skala 1 (dibawah rata-rata/tidak penting) sampai dengan 4 sangat baik. Berikut adalah table hasil perhitungan matrik EFAS. Nilai rating kekuatan dan kelemahan selalu bertolak belakang, begitu juga dengan peluang dan ancaman. Hasil analisis dari EFAS dapat dilihat pada table berikut.

Bobot untuk faktor eksternal didapatkan dari menjumlahkan setiap rating pada setiap pertanyaan kemudian membagi dengan total pengolahan data faktor eksternal kuisioner. Perhitungan rating untuk faktor peluang kekuatan didapat dari total jumlah rating jawaban responden dibagi dengan jumlah responden. Dan perhitungan skor untuk factor kekuatan didapat dari perkalian bobot dan rating.

Maka total hasil perhitungan skor matriks IFAS dan EFAS adalah sebagai berikut :

- Total skor kekuatan (strengths) = 2,972.

- Total skor kelemahan(weaknesses $)=1,104$.

- Total skor peluang (opportunities $)=1,915$.

- Total skor ancaman (threats) $=2,404$.
Diagram Cartesius Analisis SWOT. Dari hasil perhitungan pada faktor-faktor tersebut maka dapat digambarkan dalam Diagram SWOT, dapat dilihat pada gambar 4. Titik koordinatnya $(\mathrm{x}, \mathrm{y})$ diperoleh dengan cara sebagai berikut :

- Koordinat analisis internal (X)

$$
\begin{aligned}
& =\frac{\text { Total skor kekuatan }(S)-\text { Total skor kelemahan }(W)}{2} \\
& =\frac{2,972-1,104}{2}=0,933
\end{aligned}
$$

- Koordinat analisis eksternal (Y)

$$
\begin{gathered}
=\frac{\text { Total skor peluang }(O)-\text { Total skor ancaman }(T)}{2} \\
=\frac{1,915-2,404}{2}=-0,244
\end{gathered}
$$

- Jadi, titik koordinatnya terletak pada $(0,933 ;-0,244)$

Matriks SWOT. Alat yang dipakai untuk merumuskan alternatif strategi perusahaan adalah matriks SWOT. Nilai total dari faktor internal dan eksternal dapat digambarkan pada diagram analisis SWOT serta rumus kombinasi matrik SWOT. Rumusan alternatif strategi merupakan alternatif yang digunakan untuk perusahaan yang menjalankan usaha atau strategi lain ke depannya. Berikut ini adalah hasil dari kombinasi matrik yang didapat dari indikator dan dilakukan kombinasi antara faktor internal dan eksternal. 


\section{Gambar 2}

\section{Diagram CartesiusSWOT}

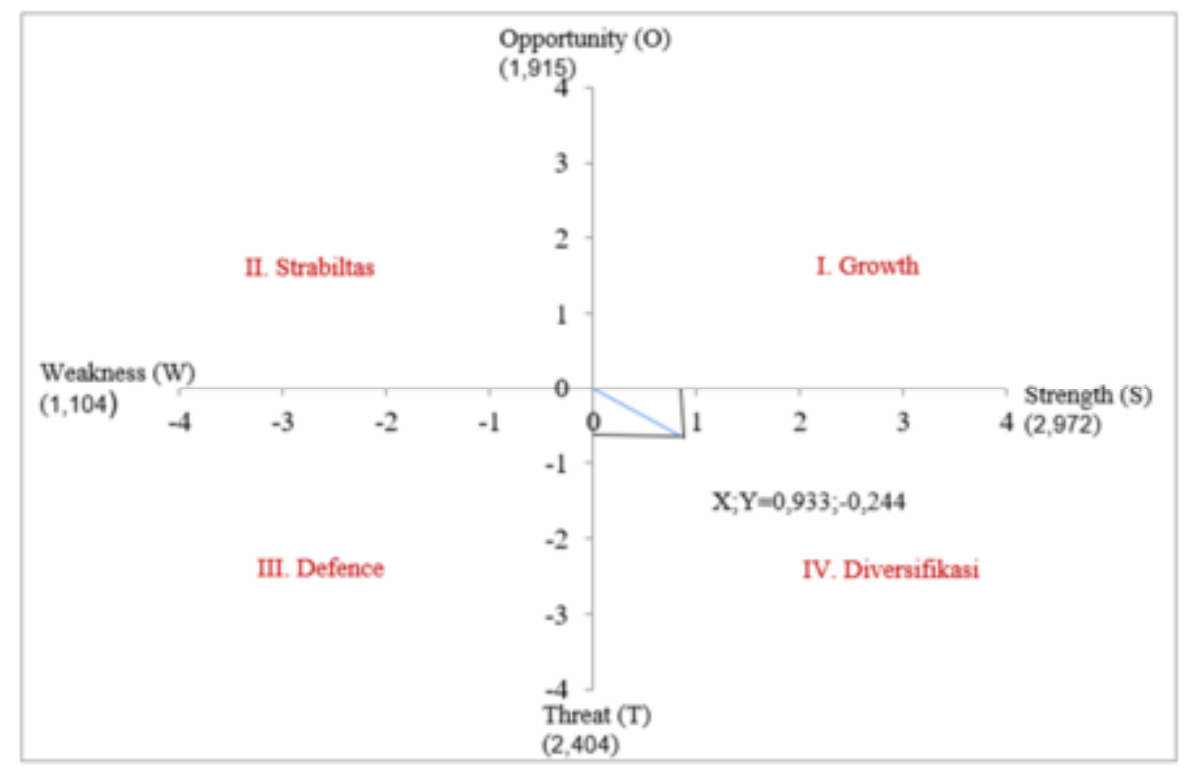

IFAS (Internal Factors Analysis Summary)

Strength :

1. Produk yang di butuhkan dapat ditemukan dengan mudah pada layanan $e$ commerce

2. Kemudahan menggunakan teknologi keuangan (fintech) dan layanan $e$-commerce

3. Kemudahan akses e-commerce dan fintech

4. Kecepatan pemberian informasi produk yang dibutuhkan baik dalam layanan $e$ commerce dan teknologi keuangan (fintech)

5. Struktur informasi yang diberikan ecommerce dan fintech mudah dipahami

6. Penggunaan media e-commerce dan fintech dapat mengefisiensi waktu yang di butuhkan

7. Penggunaan media e-commerce dan fintech dapat mengefisiensi biaya yang di butuhkan

8. Kepuasan konsumen saat penggunaan teknologi keuangan (fintech) dan ecommerce

9. Keinginan merekomendasikan fintech dan -commerce kepada pihak lain

Weakness :
1. Teknologi keuangan (fintech) masih belum dikenal secara luas

2. E-commerce masih belum dikenal secara luas

3. Kepercayaan pengguna untuk keamanan dalam menggunakan e-commerce yang masih rendah

4. Kepercayaan pengguna untuk keamanan dalam teknologi keuangan (fintech) yang masih rendah

EFAS (External Factors Analysis Summary) Opportunity:

1. Perubahan gaya hidup masyarakat saat ini.

2. Kemajuan teknologi yang berkembang saat ini

Threats :

1. Krisis ekonomi global.

2. Pandemi COVID-19 yang belum selesai S-O

1. Selalu memberikan produk dan informasi yang dibutuhkan pelanggan. (S1, S2, S3, S4, S5, O1)

2. Menyediakan kemudahan dalam memahami struktur informasi dan kecepatan akses informasi produk. (S6, $\mathrm{O} 2$ ) 
3. Selalu memberikan kemudahan akses dan memperbaharui teknologi digital yang dimiliki agar terus dapat memberikan yang dibutuhkan pelanggan. (S7, S8, S9, $\mathrm{O} 2)$

\section{W-O}

1. Memberikan literasi/ pengetahuan kepada seluruh lapisan masyarkat tentang kemudahan menggunakan layanan produk digital seperti e-commerce dan fintech. (W1, W2, O1)

2. Memberikan pengetahuan mengenai jaminan keamanan dalam penggunaan fintech dan e-commerce. (W3, W4, O2)

\section{S-T}

1. Selalu memberikan informasi produk yang dibutuhkan dengan berbagai harga dan kualitas sesuai dengan kebutuhan pelanggan (S1, S2, S3, S4, S5, T1)

2. Memantau turun naiknya nilai tukar rupiah kemudian menyesuaikan harga produk yang berpengaruh terhadap harga jual di platform e-commerce dan menyesuaikan biaya bahan baku impor akan digunakan untuk memproduksi atau membuat sarana fintech. (S6, S7, T1)

3. Menyediakan produk-produk yang sesuai kebutuhan pelanggan di situasi apapun termasuk saat Pandemi covid 19 dan era New Normal (S1, S8, S9, T2)

\section{W-T}

Memberikan literasi/pengetahuan kepada seluruh lapisan masyarkat tentang efisiensi waktu dan biaya yang digunakan ketika menggunakan layanan produk digital seperti e-commerce dan fintech. (W1, W2, T1)

1. Memberikan pengetahuan mengenai risiko bertransaksi menggunakan kontak fisik saat pandemi COVID-19 dan jaminan keamanan produk dan kesehatan dalam penggunaan fintech dan $e$ commerce. (W3, W4, T2)

Setelah melakukan matriks SWOT selanjutnya membuat analisis model kuantitatif sebagai dasar jumlah nilai skor pada tiap-tiap faktor yang ada pada masingmasing strategi S-O, W-O, S-T dan W-T. Berikut adalah tabel model kuantitatif rumusan strategi.

Perhitungan nilai S-O, W-O, S-T, W-T

adalah sebagai berikut.

- Perhitungan untuk S-O :

Total skor Strength $(\mathrm{S})+$ total skor

Opportunities $(\mathrm{O})=2,972+1,915=4,887$

Perhitungan untuk W-O :

Total skor Weakness $(\mathrm{W})+$ total skor

Opportunities $(\mathrm{O})=1,104+1,915=3,019$

Perhitungan untuk S-T :

Total skor Strength $(\mathrm{S})+$ total skor

$\operatorname{Treaths}(\mathrm{T})=2,972+2,404=5,376$

Perhitungan untuk W-T :

Total skor Weakness (W) + total skor Treaths $(\mathrm{T})=1,104+2,404=3,508$

Pembahasan Teoritis. Analisis SWOT adalah identifikasi berbagai faktor secara sistematis untuk merumuskan strategi perusahaan. Analisis ini didasarkan pada logika yang dapat memaksimalkan kekuatan (Strengths) dan peluang (Opportunities), namun secara bersamaan dapat meminimalkan kelemahan (Weakness) dan ancaman (Threats). (Samejima et al., 2006). Kekuatan dan kelemahan adalah faktor internal (terkendali) yang mendukung dan menghalangi organisasi untuk mencapai misinya masingmasing. Sedangkan peluang dan ancaman adalah fakto reksternal yang sulit di prediksi (Dyson, 2004). Dengan mengidentifikasi empat faktor ini, sebuah strategi digitalisasi ekonomi dapat dikenali perannya terhadap pertumbuhan ekonomi, karena dengan mengenali dan menganalisa keempat faktor yaitu kekuatan, kelemahan, peluang dan ancaman dari sebuah strategi yang ada maka akan didapat kompetensi untuk pengambilan keputusan, perencanaan dan pengembangan yang tepat. 
Tabel 12

Model Kuantitatif RumusanStrategi

\begin{tabular}{|c|c|c|}
\hline IFAS & Strength (S) & Weakness (W) \\
\hline $\begin{array}{c}\text { Opportunities } \\
\text { (O) }\end{array}$ & $\begin{array}{l}\text { Strategi S-O : menggunakan } \\
\text { kekuatan untuk memanfaatkan } \\
\text { peluang }=4,89\end{array}$ & $\begin{array}{l}\text { Strategi W-O : meminimalkan } \\
\text { kelemahan dengan } \\
\text { memanfaatkan peluang }=3,02\end{array}$ \\
\hline $\begin{array}{l}\text { Threats } \\
\text { (T) }\end{array}$ & $\begin{array}{l}\text { Strategi S-T : menggunakan } \\
\text { kekuatan untuk mengatasi } \\
\text { ancaman }=5,38\end{array}$ & $\begin{array}{l}\text { Strategi W-T : meminimalkan } \\
\text { kelemahan dan menghindari } \\
\text { ancaman }=3,51\end{array}$ \\
\hline
\end{tabular}

Berberapa contoh bagian dari proses digitalisasi ekonomi adalah adanya teknologi keuangan dan e-commerce. Teknologi keuangan atau yang biasa disebut sebagai fintech adalah penggunaan teknologi di dalam dunia keuangan yang menciptakan kemudahan (Arner et al., 2015). Teknologi financial juga di sebut sebagai suatu bidang bisnis yang mengarah kepada penyedia layanan keuangan dengan perangkat lunak dan teknologi modern di dalamnya. (Weekly, 2017)

Sesuai dengan teori sebelumnya mengenaianalisis SWOT dan proses digitalisasi, pada penelitian ini akan mencari strategi digitalisasi ekonomi, e-commerce, dan fintech yang tepat untuk dapat meningkatkan pertumbuhan ekonomi wilayah Sumatera dengan 10 provinsi di dalamnya. Analisa SWOT yang merupakan analisa suatu strategi dilihat dari 4 faktor kekuatan, kelemahan, peluang dan ancaman yang ada di dalam strategi tersebut.

\section{Relevansi Serat konfirmasi Riset} Terdahulu. Penelitian ini menggunakan analisa SWOT untuk menentukan strategi digitalisasi ekonomi terbaik khususnya fintech dan e-commerce. Setelah dilakukan analisa maka hasil pada penelitian ini adalah melakukan diversifikasi produk/ teknologi baik e-commerce dan fintech serta menjalankan strategi S-T yaitu menggunakan kekuatan untuk mengatasi ancaman. Analisa SWOT dilakukan sejalan dengan (Coman \& Ronen, 2009) yang menyatakan bahwa analisis SWOT telah dipuji karena kesederhanaannya dan telah digunakan terus digunakan sejak 1960-an.

Sejalan juga dengan penelitian yang dilakukan oleh (Phadermrod et al., 2019) mengenai analisis SWOT berbasis Importance-Performance Analysis yang menyatakan bahwa analisis SWOT adalah alat yang umum digunakan untuk perencanaan strategis, secara tradisional merupakan bentuk brainstorming. Faktor SWOT dapat diprioritaskan signifikansinya sehingga dapat mengakibatkan tindakan strategis yang tepat.

Justifikasi Penelitian. Setelah dilakukan penyebaran kuisioner secara menyeluruh di 10 provinsi di wilayah Sumatera didapatkan 92 responden untuk diteliti hasil jawabannya. Setelah didapatkan jawaban dengan di konversi dengan skala likert 1-5 dengan indicator tidak setuju sampai dengan sangat setuju dilakukan perhitungan rating, bobot dan skor. Kemudian dilakukan analisa pada setiap matriks SWOT IFAS dan EFAS. Setelah dilakukan analisa, maka skor 
tertinggi ada pada strategi S-T sebesar 5,38 yaitu menggunakan kekuatan untuk mengatasi ancaman. Adapun detail dari strategi tersebut adalah sebagai berikut

a. Selalu memberikan informasi produk yang dibutuhkan dengan berbagai harga dan kualitas sesuai dengan kebutuhan pelanggan.

b. Memantau turun naiknya nilai tukar rupiah kemudian menyesuaikan harga produk yang berpengaruh terhadap harga jual di platform e-commerce dan menyesuaikan biaya bahan baku impor akan digunakan untuk memproduksi atau membuat sarana fintech.

c. Menyediakan produk-produk yang sesuai kebutuhan pelanggan di situasi apapun termasuk saat pandemic covid 19 dan era New Normal.

Selain menerapkan strategi S-T yaitu menggunakan kekuatan untuk mengatasi ancaman, strategi diversifikasi produk/ teknologi juga harus diterapkan untuk meningkatkan pertumbuhan ekonomi wilayah Sumatera, Indonesia.

Sesuai dengan diagram cartesius diatas, diversifikasi produk/ teknologi digitalisasi ekonomi harus dilakukan baik untuk $e$ commerce maupun teknologi keuangan (fintech). Hal ini untuk dapat menjangkau konsumen/pasar lebih luas dan lebih banyak sehingga dapat mendorong pertumbuhan ekonomi di wilayah Sumatera, Indonesia.

\section{SIMPULAN}

Analisa SWOT adalah kegiatan menentukan strategi yang dalam hal ini adalah strategi digitalisasi ekonomi terbaik khususnya fintech dan e-commerce untuk kemudian strategi tersebut dapat diterapkan sehingga dapat meninggkatkan pertumbuhan ekonomi wilayah Sumatera, indonesia.
Setelah dilakukan uji validitas terhadap instrument pertanyaan dan jawaban 92 responden maka terdapat beberapa pernyataan yang tidak valid, yaitusoal no S2, W5, O3, O4, O5, O6 dan T2. Maka, 7 pernyataan tersebut tidak digunakan lagi ke perhitugan selanjutnya karena dinyatakan tidak valid. Setelah dilakukan uji validitas dan uji reliabilitas dan hasilnya bahwa instrument pertanyaan untuk analisis SWOT dapat di handalkan. Setelah dilakukan uji validitas dan reliabiltas maka hasil dari posisi diagram cartesius pada penelitian ini adalah melakukan diversifikasi produk/teknologi baik e-commerce dan fintech. Dan setelah melakukan analisa IFAS dan EFAS terhadap 4 faktor yaitu S-O, W-O, S-T, dan W-T strategi terbaik untuk penerapan digitalisasi ekonomi, e-commerce, dan fintech untuk mendorong pertumbuhan ekonomi wilayah Sumatera, Indonesia adalah S-T yaitu menggunakan kekuatan untuk mengatasi ancaman.

Dalam menjalankan strategi digitalisasi ekonomi, fintech, dan e-commerce berdasarkan analisis SWOT terdapat beberapa factor penghambat antara lain :

a. Ancaman krisis ekonomi global yang kemungkinan berdampak pada perekonomian di wilayah Sumatera, Indonesia.

b. Pandemi COVID-19 yang belum selesai mengakibatkan ketidakpastian kondisi ekonomi makro global maupun wilayah Sumatera, Indonesia.

c. Teknologi keuangan (fintech) dan $e$ commerce masih belum dikenal secara luas dan menyeluruh.

d. Kepercayaan pengguna untuk keamanan dalam menggunakan fintech dan $e$ commerce yang masih rendah. 


\section{DAFTAR PUSTAKA}

Abrazhevich, D. (2004). Electronic payment systems: A user-centered perspective and interaction design. Dennis Abrazhevich.

Arner, D. W., Barberis, J., \& Buckley, R. P. (2015). The evolution of Fintech: A new post-crisis paradigm. Geo. J. Int'l L., 47, 1271.

Blackman, C. R., Halewood, N. J., Kelly, T. J. C., Stefanski, S. E., Wave, V., \& Yonazi, E. (2014). ICTs for financial services in Africa. The World Bank.

Cohen, L. (2007). Experiments, quasiexperiments, single-case research and meta-analysis (Cohen, L., Manion, L., \& Morrison, $K$. in Eds) Research methods in education.(6th eds.). London: Routledge Falmer.

Coman, A., \& Ronen, B. (2009). Focused SWOT: Diagnosing critical strengths and weaknesses. International Journal of Production Research, 47(20), 5677-5689. https://doi.org/10.1080/0020754080214613 0

Daft, R. L., Murphy, J., \& Willmott, H. (2010). Organization theory and design. Cengage learning EMEA.

Doughty, H. A. (2014). Don Tapscott The Digital Economy Anniversary Edition: Rethinking Promise and Peril in the Age of Networked Intelligence New York, N.Y.: McGraw-Hill, 2014. The Public Sector Innovation Journal, 19(3), 1-6.

Dyson, R. G. (2004). Strategic development and SWOT analysis at the University of Warwick. European Journal of Operational Research, 152(3), 631-640. https://doi.org/10.1016/S03772217(03)00062-6
Hill, T., \& Westbrook, R. (1997). SWOT Analysis: It's Time for a Product Recall. Long Range Planning, 30(1), 46-52. https://doi.org/10.1016/S00246301(96)00095-7

Mahmud, D. H., \& Si, M. (2011). Metode Penelitian Pendidikan, Bandung: CV. Pustaka Setia.

Phadermrod, B., Crowder, R. M., \& Wills, G. B. (2019). Importance-Performance Analysis based SWOT analysis. International Journal of Information Management, 44, 194-203.

https://doi.org/10.1016/j.ijinfomgt.2016.03. 009

Rangkuti, F. (2004). Analisa SWOT Teknik Membedah Konsep Perencanaan Strategi Untuk Menghadapi Abad 21. Jakarta: Gramedia Pustaka Utama.

Rangkuti, F. (2019). Teknik Membedah Kasus Bisnis Analisis SWOT: Cara Perhitungan Bobot, Rating dan OCAI.

Samejima, M., Shimizu, Y., Akiyoshi, M., \& Komoda, N. (2006). SWOT analysis support tool for verification of business strategy. 2006 IEEE International Conference on Computational Cybernetics, $1-4$.

Santoso, G. (2005). Metodologi penelitian kuantitatif dan kualitatif. Jakarta: Prestasi Pustaka.

Sugiyono, M. P. P., \& Kuantitatif, P. (2009). Kualitatif, dan R\&D, Bandung: Alfabeta. Cet. VII.

Sugiyono, P. D. (2013). Metode penelitian kuantitatif dan kualitatif dan R\&D [Quantitative and qualitative and $\mathrm{R} \& \mathrm{D}$ research methods]. Bandung, Indonesia: Alfabeta.

Weekly, F. (2017). FinTech definition. 